Article

\title{
The Impact of the Implementation of Cohesion Policy on the Sustainable Development of EU Countries
}

\author{
Ramona Pîrvu ${ }^{1, *}$, Cristian Drăgan ${ }^{1}$, Gheorghe Axinte ${ }^{2}$, Sorin Dinulescu ${ }^{1}$, \\ Mihaela Lupăncescu ${ }^{1}$ and Andra Găină ${ }^{1}$ \\ 1 Department of Economics, Accounting and International Affairs, University of Craiova, \\ Craiova 200585, Romania \\ 2 Agroturistic Management Faculty, University Bioterra Bucharest, Bucharest 013722, Romania \\ * Correspondence: ramopirvu@gmail.com; Tel.: +40-0722-912-316
}

Received: 5 July 2019; Accepted: 27 July 2019; Published: 2 August 2019

\begin{abstract}
The impact of implementation of cohesion policy on the sustainable development of EU countries is of great interest and presents a number of actual challenges. This research aims to evaluate the impact and the effects of the cohesion policy among the Member States using hierarchical clustering analysis in order to identify how the selected variables affect the sustainable development adopted models. The variables used in the analysis were selected on the basis of official data provided by the European Commission, SDG Index and Dashboards Reports and the EU Cohesion Monitor. The results of the research have led to the grouping of the 28 Member States in a number of six clusters, identifying performers but also those countries that have a high potential for sustainable development or which require increased attention to be sustained in recovering existing gaps. The results of the study can be a starting point for policy makers and other stakeholders involved in their efforts to support sustainable development through effective and effective policies.
\end{abstract}

Keywords: sustainable development; EU cohesion policy; SDG Index; EU Cohesion Monitor; cluster analysis

\section{Introduction}

Economic competitiveness and economic growth have been and continue to represent from the perspective of government policies the central element of long-term development policies of more or less disadvantaged countries at European Union level. The importance of these objectives, their compatibility and their complementarity often raise questions from the perspective of the coherence of European economic policies, but also from the perspective of sustainable regional development.

Given the importance and the existing debates on EU cohesion policy as well as the major concerns regarding sustainable development and compliance with the Sustainable Development Goals (SDGs), we have designed to analyze how cohesion policy influences the sustainable development model adopted by each of the EU countries, and also the level of performance they have so far achieved in this direction.

Thus, the priority issue is to define a cohesion policy that is compatible with both the performing and the least developed countries, thus favoring economic convergence but also eliminating regional polarization [1]. Moreover, in the context of EU regional development, cohesion policy and sustainable development converge into a common economic strategy. However, the scientific analysis of compatibility or incompatibility between the two is particularly relevant in the new European context, where most regions benefit from a coherent cohesion policy in their attempts to implement sustainable development strategies. 
Based on these considerations, the present paper starts from the analysis of the correlation of the effects of the implementation of the economic cohesion policy with the achievement of the sustainable development objectives, asking whether they should be seen as promoting regional polarization instead of territorial cohesion [2-6].

Taking into account the theoretical and practical aspects of sustainable development, we also point out that cohesion policy at EU level is one of the most viable ways of consistently managing the potential of each country by reducing regional disparities by implementing measures that ensure that the needs of the current generation are met without diminishing the needs of future generations [7].

From another perspective, we also identify different points of view of the environmental performance of cohesion policy, as well as the notion that the current approach does not allow opportunities to improve it. In practice, the ecological performance of cohesion policy must take account of missed opportunities to minimize costs and increase earnings. These aspects lead to the idea that cohesion policy currently lacks sufficient opportunities to foster development on all levels [8-11].

Not to be neglected is that the concept of sustainable development has come to guide the policies and actions of both public and private organizations and to facilitate communication between actors from different spheres of society. However, previous research has found that when policymakers support sustainable development, the social dimension draws less attention and is particularly difficult to control and operationalize [12]. However, over the last few years' efforts by policy makers to develop theoretical frameworks for defining and studying sustainability, to explain the challenges of integrating sustainability in a broader context, namely that of cohesion policy.

This article contributes to a clearer understanding of what cohesion policy implementation means in the context of sustainable development and how it is reflected in country performance. The importance of understanding concepts such as public awareness, equity, participation and cohesion that are absolutely essential in the functioning and promotion of the sustainable development of all states is mentioned.

In fact, we are talking about an evolution of how cohesion policy has evolved in the EU regions in recent years, but also of an impact of national policies, cohesion policy and other EU policies on economic development, social inclusion, sustainable development, improving administrative structures. The review of the measures generating European effectiveness, the way in which Structural Funds and investment funds are allocated to good economic governance are also important issues addressed in this paper.

Also, through our research we aim to identify the level of performance of Member States in terms of cohesion policy at the level of the European Union and their impact on their sustainable development.

The paper is divided into five sections, stating with a brief introduction, followed by literature review. Section 3 includes information on the sample, variables, and the hierarchical cluster analysis methodology used in estimating the existing clusters. Further, in Section 4 the main results are debated and Section 5 offers the main conclusion of the research.

\section{Literature Review}

The role and the importance of cohesion policy as a means of promoting the change and development of European states is undeniable. The review of post-2013 policies was supported by the impact of the European Commission's proposals that were partially effective due to resistance and tensions at the level of the EU Member States. Resilience to change can be explained and sustained by the institutional interests, governance objectives and policy promoted for Europe 2020 [13-16].

From the point of view of the effectiveness of implementation, the cohesion policy at the level of the member countries can be analyzed mainly from the perspective of the EU enlargement phenomenon, a phenomenon marked by the inclusion of post-socialist countries in Central and Eastern Europe (CEE). This important step in European policy has faced the challenge of integrating regions with very different levels of economic development, which has affected and still affects the convergence and efficiency of European policies, implicitly of cohesion policy [16,17]. 
We also highlight that the problem persists, and we are currently identifying regional processes of polarization and peripheralization that are largely due to the integration of all regions of the EU. In fact, the European market, after 2004, moved east, thus incorporating relatively low economic productivity but also weak institutional bodies of the new Member States [18]. Consequently, cohesion policy has been redirected to support all EU states, especially those in the CEE. With substantial investments, particularly in less developed regions, in the new Member States, cohesion policy was also geared towards neutralizing the negative economic consequences of the integration of less developed regions into the EU $[19,20]$.

By allocating funds in line with the partnership principle, Cohesion Policy has been transposed into national development plans in CEE countries so that the use of European funds can be achieved through strategic investment programs negotiated with the European Commission and structured in Operational Programs [21-24]. As a consequence, cohesion policy has been the subject of many debates, because each programming period for the next seven years has created debates for new reforms and new development opportunities. As such, cohesion policy has been subjected both to radical and incremental reforms in recent decades, including the reorientation of cohesion policy towards the Lisbon Agenda [25-28].

It is also important to highlight in this context the fact that, from the perspective of the evolution of the EU, we identify three political periods decisive for the future of Europe. Thus, we identify the "Europe of the Regions" period from the 1990s to the early 2000s; the Lisbon Agenda for the period 2000-2010; and the Europe 2020 period, around 2010-2020 [29]. Thus, cohesion policy has practically developed in several stages orienting regional development towards economic competitiveness, sustainable economic growth through innovation and innovation [1,19].

However, we still identify countries where regional inequalities are relatively high even though sustainable development projects funded through EU programs are numerous. We basically identify in these situations a set of contradictions between the policy objectives, the requirements of cohesion policy and the practical possibilities in some less developed European regions [30-32]. We can point out that the general guidelines for internal policies at the level of each state on cohesion and sustainable development may be present in binding national documents. Cohesion policy can therefore be tracked in terms of content and implementation methods across European countries.

It is also important to look at the issue of convergence of cohesion policy with regional policy at the level of each European state. This is because regional policies can have different effects in different countries, because each country has a political, economic, social profile, which generates regional inequalities. We support this statement, including through the quotas of cohesion policy budgets allocated to specific objectives, which varied considerably in Central and Eastern Europe in 2014-2020 [33]. In the same sense, the Strategy for smart, sustainable and inclusive growth (European Commission 2010) responded to the problems of the economic crisis, which was based, in particular, on the concept of smart specialization, bringing in the concept of "innovation" an essential part of cohesion policy [17].

With regard to the Europe 2020 Strategy, it has as a general objective to promote innovation in a variety of policies, instruments, measures and funds to improve framework conditions for knowledge-intensive products and services. We identify agreements establishing national programs for the 2014-2020 period, focusing in particular on economic competitiveness and less on socio-economic convergence as a driver of sustainable urban development strategies through cohesion policy [27,34]. Overall, it appears that the EU is still in difficulty to meet the policy objectives set out in the Lisbon Agenda and the Europe 2020 Strategy, with regional disparities still remaining, issues identified by specific indicators, i.e., the number of people at risk of poverty or social exclusion.

The views are relatively similar when we want to list the main causes of regional disparities, most specialists claiming that the asymmetric economic integration of European countries is the main argument. On the other hand, we further identify the specialization of developed countries in high-tech, 
high-efficiency services, compared to less developed countries, where we are focusing mainly on basic services, less knowledge-based and where incomes are still reduced [21,35-39].

Regarding the implementation of sustainable development principles through concrete actions correlated with the objectives of EU cohesion policy, we note that regional and local communities play a crucial role. On the other hand, literature reports that the local or community level becomes critical in addressing long-term political issues such as ecological degradation or emerging risks due to ecosystem dynamics and socio-economic change [40,41]. In this context, the concept of governance of European policies appears to be particularly important, by targeting them to all actors involved, regardless of the level or sector concerned. Their involvement in defining sustainable development policies is equally important [42].

The inclusion of different actors with different expertise in resource use and protection is needed to better address the complexity of green systems, and an integrated policy approach allows for more efficient management of change management activities. Thus, promoting concepts such as "integrated management", "adaptive management", "collaborative management" or "co-management" as basic elements of network operation becomes an important step in the implementation of cohesion policy that approaches complexly and dynamically sustainable development of society [43].

In this context, it is important to identify new forms of policy-making based on the concept of network governance, how they can influence cohesion policy in a particular region, and how these changes can be assessed in terms of the performances of those regions. For this reason, it can be argued that a region must mainly reach a certain level of cohesion between different sectors of society and government institutions to successfully create and implement a policy or project aimed at strengthening development sustainable development of a region. However, in order to support the positive development of the region in the long term, we support the idea that flexibility should be maintained at the level of each region in terms of adapting to socio-economic and environmental trends [34,44].

Cohesion policy also encourages regions and cities in different EU Member States to collaborate and learn from each other through joint collaboration through programs, projects and networks with a concrete impact on every economic aspect including innovation, accessibility, education, business, employment or the environment $[45,46]$.

In this context, it is necessary to assess the impact of investments and of all actions undertaken as a result of the implementation of cohesion policy on the environment and of the way in which the requirements of sustainable development have been integrated at the strategic level. The analysis of data available at EU level, in particular on expenditure, provides relevant information and can also be operationalized in formulating recommendations for improving the integration of sustainable development into cohesion policy. The quantification of cohesion factors between EU countries is achieved through the data provided by the EU Cohesion Monitor report, which identifies a series of specific indices and quantifies how strong cohesion is. EU Cohesion Monitoring also refers to the measurement of the awareness, training and cooperation spirit of the analyzed companies [30,47].

At the same time, we identify two dimensions of cohesion, individual and structural. Individual cohesion measures citizens' experiences, views and direct expectations, and structural cohesion measures the macroeconomic cohesion of policies, the state and the economy. Among the relevant indicators in the dimension of the level of individual cohesion, we identify: experience, involvement, attitudes, approval and expectations, and from the point of view of structural cohesion we identify: resilience, economic ties, financing and security $[47,48]$.

Integration of sustainable development objectives into EU policies and initiatives is thus an undeniable subject, with the European Commission regularly reporting from 2017 on the progress made by the EU in implementing the Agenda 2030, with the main aim of defining a long-term vision longer in a post 2020 perspective. The Commission also operates a multi-platform platform to exchange best practice information on GSP implementation in sectors, at Member State and EU level. In practice, regions are classified according to their gross domestic product (GDP) as being more developed or less 
developed and the level of investment reflects the development needs of the Member States. This is also a starting point for the EU to fund a project with a percentage between $50 \%$ and $85 \%$. We underline that the overall policy goal is to make Europe's regions and cities more competitive, while encouraging growth and job creation.

From the point of view of the effects of implementing the cohesion policy at EU level in the context of meeting the provisions of the Agenda 2030 for sustainable development, we can mainly identify the creation of the necessary framework for collaboration and applicable in all European countries, which is a new ambitious model to respond to trends and global challenges. Thus, both the European community and the international community have a new ambitious framework for all countries to work together on common challenges. For the first time, sustainable development objectives are universally applicable to all countries and the EU is committed to becoming a first factor in their implementation [49].

The importance given by the European Commission to achieve the objectives set out in the 2030 Agenda is underlined by the concrete and consistent measures implemented at European level. European officials insist that "Sustainability is a European Brand", relying on the fact that the EU has a strong track record with a high level of economic development and social cohesion, and the commitment to sustainable development is anchored in EU treaties [50]. The 2030 Agenda will be integrated though two main streams: firstly, the integration of the Development Goals into the EU policy framework and the main Commission priorities; and second, is to develop a long-term vision after 2020 and the focus of sectoral policies. Thus, the efforts made at European level in the field of sustainable development, as well as the results achieved so far, place the European Union in a highly advanced position regarding the fulfillment of the undertaken development objectives.

The effects of implementing cohesion policy also consist of the responses that each state promotes to stimulate growth over time. On the other hand, strong regional polarization suggests the need to stimulate the interaction of all states for the next programming period of EU development [51]. Indeed, at a time of uncertainty about the positive effects of cohesion policy and the very meaning of cohesion, it is clear that efforts must be made to demonstrate its relevance, particularly during the post neo-liberal period.

\section{Research Methodology}

\subsection{Sample Selection and Variables}

In order to assess the impact of cohesion policy on the sustainable development of EU countries and the links between these factors, the official data provided by the European Commission [52], the SDG Index and Dashboards Reports [53] and the EU Cohesion Monitor [47].

Thus, the level of sustainable development achieved by EU countries was assessed through individual scores calculated in the SDG Index and Dashboards Report, published by the UN Sustainable Development Solutions Network in cooperation with the Bertelsmann Stiftung. The SDG Index is the first ever worldwide study to assess the country's reach of Sustainable Development Goals, and is designed to complement the official indicators set to monitor ODL achievement. For calculating the scores included, data provided by official data providers such as the World Bank, the World Health Organization, the International Labor Organization, and other organizations, including research centers and non-governmental organizations, have been taken into account. The SDG calculated for each analyzed country includes all data available for each of the 17 SDGs in part, aggregating them into a composite index to provide a rapid assessment of individual country performance.

Data on the share of European funds in the Gross National Income (GNI) was taken over from the European Commission and provides information on EU payments for Structural and Investment Funds programs. The data are reported cumulatively, ie the amounts indicated in 2018 represent cumulative payments made from the beginning of the programming period (2014-2018). 
In order to quantify the values of the cohesion factors between the countries of the European Union, the data provided by the European Council of Foreign Relations and Stiftung Mercator, published in the EU Cohesion Monitor report, which computes a series of indexes for the 28 states members of the European Union regarding their readiness for joint action and cooperation. These indices analyze and quantify how strong cohesion is, how it changes and how different it is between the Member States of the European Union, the central concept being that European cohesion is a precondition for Europe's capacity to act and that acting together will, in turn, consolidate cohesion. Cohesion is broader in the sense that it focuses on the willingness of collective actors to work together. EU Cohesion Monitoring refers not only to real cooperation, but also to measuring the awareness, training and cooperation spirit of the companies under review.

The indicators computed by the EU Cohesion Monitor measure two dimensions of cohesion. Individual cohesion quantifies citizens' experiences, opinions and expectations, while structural cohesion measures the macroeconomic cohesion of policies, the state and the economy. Each dimension contains an equal number of building blocks (called indicators), each indicator being divided into factors. In this research, we took into account a total of nine indicators, of which five indicators related to individual (I) cohesion (experience, involvement, attitudes, approval and expectations) and four structural (S) cohesion characteristics (resilience, economic links, finance and security).

The synthetic values of the variables used in the proposed analysis are shown in Table 1.

Table 1. Descriptive statistics.

\begin{tabular}{llcccc}
\hline \multicolumn{1}{c}{ Variable } & N & Minimum & Maximum & Mean & Std. Deviation \\
\hline SDG Index & 27 & 70.40 & 85.00 & 77.0111 & 4.11034 \\
EU funds to GNI & 27 & 0.2767 & 3.9030 & 1.626619 & 1.1566270 \\
Experience (I) & 27 & 3.1586 & 7.7387 & 5.510226 & 1.4157750 \\
Engagement (I) & 27 & 0.3672 & 10.3659 & 6.986283 & 2.1856225 \\
Attitudes (I) & 27 & 2.6261 & 7.3471 & 5.807456 & 1.1387508 \\
Approval (I) & 27 & 2.1017 & 7.8070 & 5.167942 & 1.4716549 \\
Expectations (I) & 27 & 2.4231 & 8.7522 & 6.103123 & 1.2602841 \\
Resilience (S) & 27 & 2.3820 & 7.0770 & 5.513844 & 1.1230027 \\
Economic Ties (S) & 27 & 2.8307 & 8.7773 & 5.749819 & 1.5503099 \\
Funding (S) & 27 & 2.1813 & 7.4245 & 3.868721 & 1.4257168 \\
Security (S) & 27 & 1.0000 & 10.7429 & 4.312169 & 2.6585714 \\
Valid N (listwise) & 27 & & & & \\
\hline
\end{tabular}

Source: own construction using SPSS.

\subsection{Model and Method}

Following the preliminary analysis of the available data, it is noted that Luxembourg records values much higher than the maximum deviations accepted in the analysis, and as a consequence this country was excluded from the group of countries retained for analysis.

To assess the impact of the implementation of cohesion policy on the sustainable development of EU countries hierarchical cluster analysis has been used [54,55]. The available data have been processed and analyzed using the IBM SPSS Statistics [56] software program and Microsoft Excel [57].

For constructing the proximity matrix $\left(W=\left\|w_{i j}\right\|_{i=\overline{1, n}, j=\overline{1, n}}\right)$, with 11 variables $(m)$ and 27 countries (n), the Squared Euclidean Distance method has been used:

$$
W=\left\|w_{i j}\right\|_{i=\overline{1, n}, j=\overline{1, n}}, w_{i j}=\sqrt{\sum_{i=1}^{n}\left(z_{i k}-z_{i j}\right)^{2}}, j=\overline{1, m}, k=\overline{1, m} j \neq i, k \neq i, w_{i i}=0
$$

Later, to determine the distance between clusters, the Wards Method [58] was used:

$$
\Delta(A, B)=\sum_{i \in A \cup B}\left\|x_{i}-m_{A \cup B}\right\|^{2}-\sum_{i \in A}\left\|x_{i}-m_{A}\right\|^{2}-\sum_{i \in B}\left\|x_{i}-m_{\mathbf{B}}\right\|^{2}-\frac{n_{A \cap B}}{n_{A \cup B}}\left\|m_{A}-m_{B}\right\|^{2}
$$


The significance of the cluster variables was tested using Levene's Test, with null hypothesis being:

$$
H_{0 \_1}: \sigma_{1}^{2}=\sigma_{2}^{2}=\sigma_{3}^{2}=\ldots=\sigma_{r}^{2}
$$

The acceptance condition for accepting the null hypothesis $H_{0_{-} 1}$ is:

$$
\text { Sig.F }>\alpha \text { equivalent to } F_{\text {stat }}<F_{\alpha, r-1, n-r}
$$

If the null hypothesis is accepted, ANOVA methodology could be used to test the statistical significance of the mean values of the selected variables at the cluster level. In the case of rejection of the null hypothesis, instead of the ANOVA methodology, the Welch Test or the Brown-Forsyte Test could be used, with null hypothesis being:

$$
H_{0 \_2}: m_{k i}=m_{k j} ; i \neq j
$$

where $k$ represents the number of the variable $k=(1,11)$ and $i$ and $j$ represent the numbers of the clusters

The agglomeration schedule resulted after performing the hierarchical clustering analysis is

\begin{tabular}{|c|c|c|c|c|c|c|}
\hline \multirow{2}{*}{ Stage } & \multicolumn{2}{|c|}{ Cluster Combined } & \multirow{2}{*}{ Coefficients } & \multicolumn{2}{|c|}{ Appears } & \multirow{2}{*}{ Next Stage } \\
\hline & Cluster 1 & Cluster 2 & & Cluster 1 & Cluster 2 & \\
\hline 1 & 7 & 9 & 2.023 & 0 & 0 & 2 \\
\hline 2 & 7 & 8 & 5.367 & 1 & 0 & 23 \\
\hline 3 & 2 & 6 & 10.644 & 0 & 0 & 8 \\
\hline 4 & 3 & 4 & 16.651 & 0 & 0 & 14 \\
\hline 5 & 22 & 24 & 22.804 & 0 & 0 & 15 \\
\hline 6 & 14 & 19 & 29.551 & 0 & 0 & 15 \\
\hline 7 & 11 & 13 & 36.898 & 0 & 0 & 12 \\
\hline 8 & 2 & 5 & 45.931 & 3 & 0 & 14 \\
\hline 9 & 21 & 23 & 56.690 & 0 & 0 & 20 \\
\hline 10 & 27 & 28 & 68.126 & 0 & 0 & 21 \\
\hline 11 & 25 & 26 & 79.988 & 0 & 0 & 21 \\
\hline 12 & 11 & 17 & 92.233 & 7 & 0 & 18 \\
\hline 13 & 16 & 18 & 106.404 & 0 & 0 & 19 \\
\hline 14 & 2 & 3 & 122.604 & 8 & 4 & 19 \\
\hline 15 & 14 & 22 & 138.827 & 6 & 5 & 18 \\
\hline 16 & 10 & 20 & 161.383 & 0 & 0 & 20 \\
\hline 17 & 12 & 15 & 186.664 & 0 & 0 & 22 \\
\hline 18 & 11 & 14 & 217.569 & 12 & 15 & 22 \\
\hline 19 & 2 & 16 & 259.429 & 14 & 13 & 23 \\
\hline 20 & 10 & 21 & 304.876 & 16 & 9 & 24 \\
\hline 21 & 25 & 27 & 360.952 & 11 & 10 & 25 \\
\hline 22 & 11 & 12 & 422.765 & 18 & 17 & 24 \\
\hline 23 & 2 & 7 & 525.500 & 19 & 2 & 25 \\
\hline 24 & 10 & 11 & 647.089 & 20 & 22 & 26 \\
\hline 25 & 2 & 25 & 814.709 & 23 & 21 & 26 \\
\hline 26 & 2 & 10 & 1113.583 & 25 & 24 & 0 \\
\hline 27 & 1 & 11 & 7268.195 & 25 & 26 & 0 \\
\hline
\end{tabular}
presented in Table 2:

Table 2. Agglomeration Schedule.

Source: own construction using SPSS.

In the graphical representation of the results obtained from the cluster analysis, one can see how the analyzed countries are grouped according to the specific conditions is the form of a dendrogram. The dendrogram is a graphical representation that follows the merging or splitting steps in a hierarchical grouping solution that shows the combined clusters and distance coefficient values for each stage. 
Based on existing research $[54,59,60]$, analyzing dendrogram and cluster formation steps, we can state that a significant number of four clusters can be identified. However, given the purpose of the research and without violating the recognized methodologies for selecting the optimal number of clusters, we propose to choose a number of six clusters relevant for a better segmentation of the analyzed countries as well as for a better observation of the influences of the variables analyzed (Figure 1).

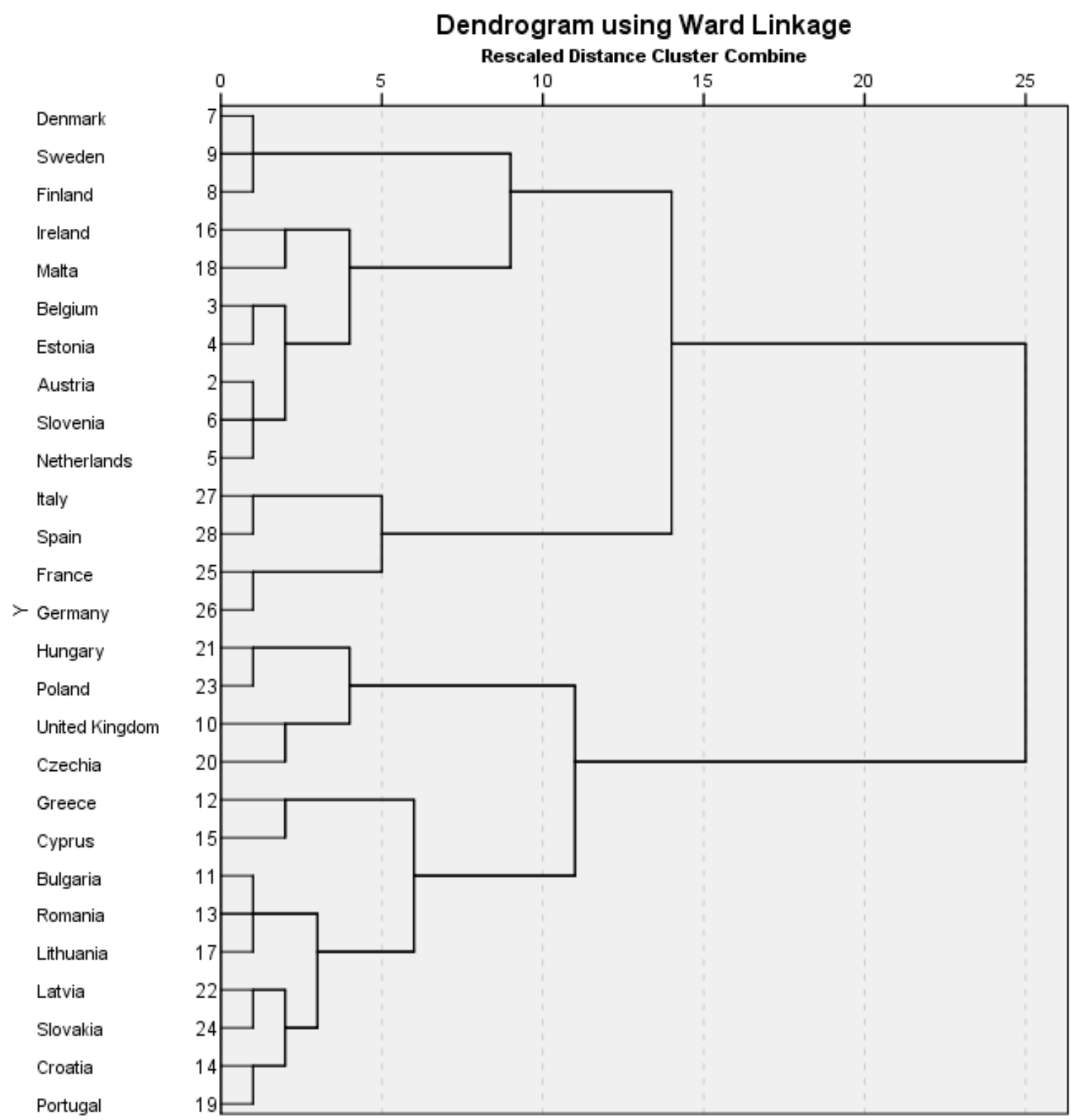

Figure 1. Dendogram of clustering. Source: own construction using SPSS.

One of the methods of testing the significance of the six cluster variables is analysis of variance (ANOVA) methodology. For the application of this method it is necessary that the dispersions of the variables satisfy the Test of Homogeneity of Variances according to the relation (3), (null hypothesis: the dispersions of the variables do not differ significantly).

As shown in Table 3, for a significance threshold of $\alpha=0.05$ (95\% confidence level), the null hypothesis $\mathrm{H}_{0_{-} 1}$ is rejected and therefore the ANOVA methodology cannot be used as it could provide inconclusive information. 
Table 3. Test of Homogeneity of Variances.

\begin{tabular}{|c|c|c|c|c|c|}
\hline & & Levene Statistic & df1 & df2 & Sig. \\
\hline \multirow{4}{*}{ SDG Index } & Based on Mean & 1.681 & 6 & 20 & 0.178 \\
\hline & Based on Median & 1.264 & 6 & 20 & 0.318 \\
\hline & Based on Median and with adjusted df & 1.264 & 6 & 12.387 & 0.341 \\
\hline & Based on trimmed mean & 1.625 & 6 & 20 & 0.192 \\
\hline \multirow{4}{*}{ EU funds to GNI } & Based on Mean & 1.649 & 6 & 20 & 0.186 \\
\hline & Based on Median & 1.334 & 6 & 20 & 0.288 \\
\hline & Based on Median and with adjusted df & 1.334 & 6 & 11.869 & 0.316 \\
\hline & Based on trimmed mean & 1.583 & 6 & 20 & 0.204 \\
\hline \multirow{4}{*}{ Experience (I) } & Based on Mean & 12.103 & 6 & 20 & 0.000 \\
\hline & Based on Median & 8.497 & 6 & 20 & 0.000 \\
\hline & Based on Median and with adjusted df & 8.497 & 6 & 8.228 & 0.004 \\
\hline & Based on trimmed mean & 11.907 & 6 & 20 & 0.000 \\
\hline \multirow{4}{*}{ Engagement (I) } & Based on Mean & 0.554 & 6 & 20 & 0.761 \\
\hline & Based on Median & 0.334 & 6 & 20 & 0.911 \\
\hline & Based on Median and with adjusted df & 0.334 & 6 & 14.233 & 0.908 \\
\hline & Based on trimmed mean & 0.503 & 6 & 20 & 0.799 \\
\hline \multirow{4}{*}{ Attitudes (I) } & Based on Mean & 1.541 & 6 & 20 & 0.216 \\
\hline & Based on Median & 1.431 & 6 & 20 & 0.252 \\
\hline & Based on Median and with adjusted df & 1.431 & 6 & 15.742 & 0.264 \\
\hline & Based on trimmed mean & 1.561 & 6 & 20 & 0.210 \\
\hline \multirow{4}{*}{ Approval (I) } & Based on Mean & 3.307 & 6 & 20 & 0.020 \\
\hline & Based on Median & 2.654 & 6 & 20 & 0.046 \\
\hline & Based on Median and with adjusted df & 2.654 & 6 & 13.879 & 0.063 \\
\hline & Based on trimmed mean & 3.183 & 6 & 20 & 0.023 \\
\hline \multirow{4}{*}{ Expectations (I) } & Based on Mean & 3.223 & 6 & 20 & 0.022 \\
\hline & Based on Median & 1.814 & 6 & 20 & 0.147 \\
\hline & Based on Median and with adjusted df & 1.814 & 6 & 12.832 & 0.174 \\
\hline & Based on trimmed mean & 3.006 & 6 & 20 & 0.029 \\
\hline \multirow{4}{*}{ Resilience (S) } & Based on Mean & 4.428 & 6 & 20 & 0.005 \\
\hline & Based on Median & 3.422 & 6 & 20 & 0.017 \\
\hline & Based on Median and with adjusted df & 3.422 & 6 & 14.119 & 0.027 \\
\hline & Based on trimmed mean & 4.302 & 6 & 20 & 0.006 \\
\hline \multirow{4}{*}{ Economic Ties (S) } & Based on Mean & 1.883 & 6 & 20 & 0.134 \\
\hline & Based on Median & 0.871 & 6 & 20 & 0.533 \\
\hline & Based on Median and with adjusted df & 0.871 & 6 & 11.140 & 0.545 \\
\hline & Based on trimmed mean & 1.563 & 6 & 20 & 0.210 \\
\hline \multirow{4}{*}{ Funding (S) } & Based on Mean & 1.499 & 6 & 20 & 0.229 \\
\hline & Based on Median & 1.185 & 6 & 20 & 0.354 \\
\hline & Based on Median and with adjusted df & 1.185 & 6 & 12.060 & 0.376 \\
\hline & Based on trimmed mean & 1.532 & 6 & 20 & 0.219 \\
\hline \multirow{4}{*}{ Security (S) } & Based on Mean & 2.249 & 6 & 20 & 0.080 \\
\hline & Based on Median & 1.799 & 6 & 20 & 0.150 \\
\hline & Based on Median and with adjusted df & 1.799 & 6 & 10.278 & 0.194 \\
\hline & Based on trimmed mean & 2.254 & 6 & 20 & 0.080 \\
\hline
\end{tabular}

Source: own construction using SPSS.

Based on the ANOVA results, to validate the method we used we decided to use the Welch Test and the Brown-Forsyte Test (Null Hypothesis $\mathrm{H}_{0 \_}$: variable averages do not differ significantly). The results of the tests for a significance threshold of $\alpha=0.05$ are presented in Table 4 . For all eleven variables, the null hypothesis $\mathrm{H}_{0 \_}$is rejected, and consequently the relationship (5), respectively, their mean values are significant in the analysis of the characteristics of the six clusters. 
Table 4. Robust Tests of Equality of Means.

\begin{tabular}{|c|c|c|c|c|c|}
\hline & & Statistic $^{a}$ & df1 & df2 & Sig. \\
\hline \multirow[t]{2}{*}{ SDG Index } & Welch & 103.838 & 6 & 5.270 & 0.000 \\
\hline & Brown-Forsythe & 27.894 & 6 & 12.418 & 0.000 \\
\hline \multirow[t]{2}{*}{ EU funds to GNI } & Welch & 4.998 & 6 & 5.488 & 0.042 \\
\hline & Brown-Forsythe & 4.042 & 6 & 6.107 & 0.045 \\
\hline \multirow[t]{2}{*}{ Experience (I) } & Welch & 8.770 & 6 & 4.517 & 0.021 \\
\hline & Brown-Forsythe & 2.029 & 6 & 1.852 & 0.050 \\
\hline \multirow{2}{*}{ Engagement (I) } & Welch & 2.716 & 6 & 4.890 & 0.049 \\
\hline & Brown-Forsythe & 6.414 & 6 & 8.768 & 0.008 \\
\hline \multirow[t]{2}{*}{ Attitudes (I) } & Welch & 2.952 & 6 & 4.660 & 0.036 \\
\hline & Brown-Forsythe & 4.006 & 6 & 8.408 & 0.035 \\
\hline \multirow{2}{*}{ Approval (I) } & Welch & 7.369 & 6 & 4.886 & 0.024 \\
\hline & Brown-Forsythe & 4.423 & 6 & 2.922 & 0.039 \\
\hline \multirow[t]{2}{*}{ Expectations (I) } & Welch & 1.787 & 6 & 5.250 & 0.044 \\
\hline & Brown-Forsythe & 2.001 & 6 & 3.227 & 0.043 \\
\hline \multirow[t]{2}{*}{ Resilience (S) } & Welch & 20.322 & 6 & 4.873 & 0.003 \\
\hline & Brown-Forsythe & 5.984 & 6 & 2.258 & 0.038 \\
\hline \multirow[t]{2}{*}{ Economic Ties (S) } & Welch & 6.281 & 6 & 5.367 & 0.027 \\
\hline & Brown-Forsythe & 3.743 & 6 & 6.790 & 0.046 \\
\hline \multirow[t]{2}{*}{ Funding (S) } & Welch & 2.328 & 6 & 5.166 & 0.082 \\
\hline & Brown-Forsythe & 2.876 & 6 & 4.725 & 0.040 \\
\hline \multirow{2}{*}{ Security (S) } & Welch & 146.103 & 6 & 4.560 & 0.000 \\
\hline & Brown-Forsythe & 28.934 & 6 & 9.362 & 0.000 \\
\hline
\end{tabular}

${ }^{a}$ Asymptotically F distributed. Source: own construction using SPSS.

Subsequently, the data obtained were tested for variance analysis using the ANOVA methodology, and the results are presented in Table 5 .

Table 5. The analysis of variance (ANOVA).

\begin{tabular}{ccccccc}
\hline & & Sum of Squares & df & Mean Square & F & Sig. \\
\hline SDG Global & Between Groups & 330.843 & 4 & 82.711 & 17.417 & 0.000 \\
Within Groups & 109.225 & 23 & 4.749 & & \\
& Total & 440.067 & 27 & & & \\
\hline Global & Between Groups & 1287.822 & 4 & 321.955 & 34.276 & 0.000 \\
Innovation & Within Groups & 216.037 & 23 & 9.393 & & \\
Index & Total & 1503.859 & 27 & & & \\
\hline \multirow{2}{*}{ Human } & Between Groups & 608.815 & 4 & 152.204 & 12.691 & 0.000 \\
Capital & Within Groups & 275.833 & 23 & 11.993 & & \\
& Total & 884.648 & 27 & & & \\
\hline \multirow{2}{*}{ Natural } & Between Groups & 208.477 & 4 & 52.119 & 2.107 & 0.041 \\
Capital & Within Groups & 568.986 & 23 & 24.739 & & \\
& Total & 777.463 & 27 & & & 0.000 \\
\hline \multirow{2}{*}{ Social } & Between Groups & 675.112 & 4 & 168.778 & 9.051 & \\
Capital & Within Groups & 428.875 & 23 & 18.647 & & \\
& Total & 1103.987 & 27 & & & 0.000 \\
Economic & Between Groups & 1920.942 & 4 & 480.235 & 17.333 & \\
Capital & Within Groups & 637.229 & 23 & 27.706 & & \\
& Total & 2558.171 & 27 & & & \\
\hline
\end{tabular}




\section{Empirical Results and Discussion}

Following the research, six relevant clusters have been identified with regard to the influence of cohesion factors and European funds on the sustainable development of EU countries (Tables 6-11).

In the Cluster ONE, the following countries were selected: Austria, Belgium, Estonia, the Netherlands, Slovenia, Ireland and Malta. The countries belonging to this cluster are characterized by high SDG Index values as well as the highest scores for four out of nine analyzed cohesion variables: Experience, Engagement, Expectations and Economic Ties. Also, the values recorded for the other variables considered are above average.

Table 6. Cluster ONE.

\begin{tabular}{clccccccc}
\hline No. & \multicolumn{1}{c}{ Variable } & Austria & Belgium & Estonia & Netherlands & Slovenia & Ireland & Malta \\
\hline 1. & SDG Index & 80 & 79 & 78.3 & 79.5 & 80 & 77.5 & 74.2 \\
2. & EU funds to GNI & 0.4732 & 1.6640 & 2.8746 & 0.3316 & 1.1247 & 0.7526 & 1.9257 \\
3. & Experience (I) & 7.0675 & 7.2108 & 7.5425 & 6.7122 & 6.9342 & 6.9570 & 6.4651 \\
4. & Engagement (I) & 3.2021 & 10.3559 & 8.0761 & 6.9062 & 8.0521 & 9.0104 & 10.2057 \\
5. & Attitudes (I) & 5.1035 & 6.8535 & 5.8926 & 6.1481 & 4.8797 & 7.3074 & 7.3471 \\
6. & Approval (I) & 4.2500 & 6.3110 & 5.3433 & 6.9587 & 6.4058 & 5.9110 & 5.7446 \\
7. & Expectations (I) & 5.6629 & 6.1494 & 6.7924 & 6.8751 & 5.9515 & 8.7522 & 8.1037 \\
8. & Resilience (S) & 6.6703 & 6.0892 & 5.7777 & 6.7581 & 5.7066 & 5.7195 & 6.9257 \\
9. & Economic Ties (S) & 6.6619 & 7.4727 & 7.3663 & 5.8024 & 7.5772 & 4.1087 & 7.1578 \\
10. & Funding (S) & 2.8658 & 4.3755 & 4.5525 & 2.6302 & 3.1093 & 2.1813 & 3.4262 \\
11. & Security (S) & 3.0000 & 4.8000 & 3.2857 & 5.2286 & 2.7143 & 2.2857 & 1.0000 \\
\hline
\end{tabular}

Source: own construction using SPSS.

Table 7. Cluster TWO.

\begin{tabular}{clccc}
\hline No. & \multicolumn{1}{c}{ Variable } & Denmark & Finland & Sweden \\
\hline 1. & SDG Index & 84.60 & 83.00 & 85.00 \\
2. & EU funds to GNI & 0.4959 & 0.6627 & 0.3102 \\
3. & Experience (I) & 5.8329 & 6.0597 & 5.6884 \\
4. & Engagement (I) & 5.6397 & 6.8427 & 7.1157 \\
5. & Attitudes (I) & 6.8924 & 6.2224 & 6.2048 \\
6. & Approval (I) & 3.1767 & 4.2014 & 3.5585 \\
7. & Expectations (I) & 6.8454 & 6.5319 & 6.7520 \\
8. & Resilience (S) & 6.8454 & 6.5319 & 6.7520 \\
9. & Economic Ties (S) & 4.5725 & 4.7544 & 4.7849 \\
10. & Funding (S) & 2.8552 & 2.9927 & 2.6737 \\
11. & Security (S) & 3.1429 & 3.9429 & 4.0857 \\
\hline
\end{tabular}

Source: own construction using SPSS.

Table 8. Cluster THREE.

\begin{tabular}{clcccc}
\hline No. & \multicolumn{1}{c}{ Variable } & United Kingdom & Czechia & Hungary & Poland \\
\hline 1. & SDG Index & 78.70 & 78.70 & 75.00 & 73.70 \\
2. & EU funds to GNI & 0.2767 & 2.1496 & 3.4266 & 2.6677 \\
3. & Experience (I) & 5.0029 & 5.4239 & 3.8014 & 3.3356 \\
4. & Engagement (I) & 4.1967 & 4.5634 & 0.3672 & 3.3311 \\
5. & Attitudes (I) & 4.5697 & 4.2737 & 5.8286 & 6.8233 \\
6. & Approval (I) & 2.2512 & 2.1017 & 3.4570 & 3.8849 \\
7. & Expectations (I) & 5.4186 & 4.5426 & 4.7689 & 5.9667 \\
8. & Resilience (S) & 5.9074 & 6.4897 & 5.0445 & 5.5055 \\
9. & Economic Ties (S) & 2.8307 & 7.8342 & 7.9014 & 6.4738 \\
10. & Funding (S) & 2.6172 & 5.1097 & 6.4904 & 4.6165 \\
11. & Security (S) & 6.2571 & 3.2857 & 3.1429 & 4.5143 \\
\hline
\end{tabular}


Table 9. Cluster FOUR.

\begin{tabular}{clccccccc}
\hline No. & \multicolumn{1}{c}{ Variable } & Bulgaria & Romania & Croatia & Lithuania & Portugal & Latvia & Slovakia \\
\hline 1. & SDG Index & 73.10 & 71.20 & 76.50 & 72.90 & 74.00 & 74.70 & 75.60 \\
2. & EU funds to GNI & 3.7635 & 2.5925 & 1.4050 & 3.9030 & 2.1057 & 2.7615 & 1.9651 \\
3. & Experience (I) & 3.6884 & 3.1586 & 4.2145 & 6.6693 & 5.2876 & 6.4685 & 5.8499 \\
4. & Engagement (I) & 7.9774 & 8.3903 & 7.7265 & 9.0293 & 8.4430 & 6.4444 & 5.0345 \\
5. & Attitudes (I) & 6.0635 & 6.3610 & 5.3319 & 7.0356 & 6.6079 & 6.1531 & 5.4257 \\
6. & Approval (I) & 5.0091 & 5.1814 & 5.2048 & 6.7937 & 4.9418 & 5.3558 & 5.7300 \\
7. & Expectations (I) & 5.4796 & 7.6283 & 5.9048 & 5.8760 & 7.6645 & 6.0524 & 5.9117 \\
8. & Resilience (S) & 4.1348 & 4.6575 & 4.1918 & 5.1166 & 4.4170 & 4.7451 & 5.8136 \\
9. & Economic Ties (S) & 5.4793 & 6.6170 & 5.9323 & 5.9928 & 5.9788 & 6.2047 & 8.7773 \\
10. & Funding (S) & 7.4245 & 5.7586 & 3.0739 & 5.3922 & 3.3144 & 5.1273 & 5.3348 \\
11. & Security (S) & 3.1429 & 3.5714 & 2.7143 & 3.1429 & 3.1429 & 3.0000 & 3.0000 \\
\hline
\end{tabular}

Source: own construction using SPSS.

Table 10. Cluster FIVE.

\begin{tabular}{clcc}
\hline No. & \multicolumn{1}{c}{ Variable } & Cyprus & Greece \\
\hline 1. & SDG Index & 70.60 & 70.40 \\
2. & EU funds to GNI & 2.8815 & 1.0969 \\
3. & Experience (I) & 3.2640 & 7.7387 \\
4. & Engagement (I) & 7.4587 & 8.6618 \\
5. & Attitudes (I) & 2.6261 & 3.8023 \\
6. & Approval (I) & 5.8215 & 6.2785 \\
7. & Expectations (I) & 2.4231 & 5.2849 \\
8. & Resilience (S) & 2.3820 & 4.7654 \\
9. & Economic Ties (S) & 3.2400 & 4.2366 \\
10. & Funding (S) & 5.1253 & 2.4103 \\
11. & Security (S) & 2.7143 & 1.2857 \\
\hline
\end{tabular}

Source: own construction using SPSS.

Table 11. Cluster SIX.

\begin{tabular}{clcccc}
\hline No. & \multicolumn{1}{c}{ Variable } & France & Germany & Italy & Spain \\
\hline 1. & SDG Index & 81.20 & 82.30 & 74.20 & 75.40 \\
2. & EU funds to GNI & 0.5811 & 0.3288 & 0.5675 & 0.8306 \\
3. & Experience (I) & 4.2596 & 5.5709 & 3.8943 & 4.6776 \\
4. & Engagement (I) & 5.8730 & 7.8194 & 6.1423 & 8.7528 \\
5. & Attitudes (I) & 5.5157 & 7.0834 & 4.7000 & 5.7483 \\
6. & Approval (I) & 5.4497 & 7.7217 & 4.6836 & 7.8070 \\
7. & Expectations (I) & 7.2829 & 4.4744 & 6.2621 & 6.0882 \\
8. & Resilience (S) & 5.9578 & 7.0770 & 4.5958 & 4.2958 \\
9. & Economic Ties (S) & 4.4388 & 4.3511 & 4.0337 & 4.6637 \\
10. & Funding (S) & 2.9529 & 2.7142 & 2.9988 & 2.3321 \\
11. & Security (S) & 10.4000 & 10.7429 & 8.7143 & 10.1714 \\
\hline
\end{tabular}

Source: own construction using SPSS.

Thus, we can consider the countries clustered in these clusters as being at a high level of performance, in which interaction with other European cultures positively influences the desire for cooperation, and the involvement of citizens in economic, social and political life is high. At the same time, the expectations of the population regarding the future of the personnel as well as the society are high and positive, and the economics of the grouped countries thus present a very high level of integration with the other European countries, which shows a significant level of cohesion.

The three most important Nordic countries were reunited in Cluster TWO, Denmark, Finland and Sweden respectively. Significant for this group of countries are the high values in terms of the level of sustainable development achieved, as well as the highest values for two of the cohesion variables analyzed: Attitudes and Resilience. With regard to a third variable, i.e., the share of European funds 
in the Gross National Income, it can be noticed that the average value specific to the three countries clustered in this cluster is the smallest of all the analyzed clusters.

Thus, the population of countries so grouped shows a positive attitude towards the European project and the other member countries and demonstrates a very high level of prosperity without conflicts that may result from economic or social inequalities, being more inclined to cooperate with citizens other countries within the European Union.

In the Cluster THREE, three Central European countries (Czech Republic, Hungary and Poland) were included alongside the UK. Specifically countries grouped in this way are characterized by relatively low values for the SDG Index, but also for the fact that they record the lowest values for three of the nine cohesion variables, namely: Experience, Engagement and Approval.

Thus, these countries can be characterized by a relatively low level of interaction with other European citizens, respectively with other EU Member States. Also, citizens of these countries have a relatively low involvement rate in European elections or favor anti-European parties or parties, and do not look optimistically or with approval on the outcome of European policies, avoiding cooperation on certain economic, political or social.

Six countries were grouped in Cluster FOUR: Bulgaria, Romania, Croatia, Lithuania, Portugal, Latvia and Slovakia. The main characteristics of these countries are the relatively low scores regarding the level of sustainable development reached, together with the highest values regarding the percentage of European funds in the National Gross National Income, respectively the structural variable "Funding", of all analyzed countries.

Thus, countries clustered in this cluster can be identified as those countries where the European Union has invested and still invests significant sums of money to reduce economic and social disparities. However, as the SDG Index indicates, this European investment process is still expected to bear fruit, the high potential of these countries in terms of cohesion being highlighted by higher than average scores for the "Engagement", "Attitudes" and "Expectations".

The FIVE Cluster is composed of only two countries, namely Cyprus and Greece. It is interesting to analyze why these two countries are viewed separately and the analysis of the data obtained from the research shows the lowest values for five of the nine analyzed cohesion variables: Attitudes, Expectations, Resilience, Economic Ties and Security.

The situation of these two countries is rather complicated compared to the rest of the analyzed countries, as the sustainable development level is relatively low, characterized by the lowest average SDG Index, and the cohesion variables analyzed do not provide sufficient support to provide support for the improvement of this condition in the near future. The analysis shows that the citizens of these countries do not see positively the European Union and the European project as a whole, but also the fact that they have little or no expectations about their future, both personally and as a country. Also, their societies are burdened with conflicts resulting from the recording of various inequalities, which directly affects the level of prosperity, as evidenced by a low level of commercial integration with the other European countries, but also a low level of security perceptions at these companies' level.

Countries considered to be the most economically important at European level were grouped in the Sixth Cluster, including France, Germany, Italy and Spain. Characteristic of these countries are the relatively low values of the SDG Index, but also extreme values for three of the nine cohesion variables analyzed, indicating the highest values for "Approval" and "Security", but also the lowest value for "Funding".

As a result of the analysis, it can be noticed that the citizens of these countries have a positive perception of the results of the implementation of the European policies, which provides a strong support for the pro-integration measures at European level and also the level of perceived security is among the higher among all analyzed countries. At the same time, it can be noted the low level of funding received from the European Union, which is not surprising if we take into account the very high level of economic development. 
In order to get an overview of the identified clusters as well as their characteristics, the variables considered for this analysis were grouped in Table 12, along with the graphical representation of identified clusters (Figure 2):

Table 12. Values of variables for analyzed clusters.

\begin{tabular}{clcccccc}
\hline No. & \multicolumn{1}{c}{ Variable } & $\begin{array}{c}\text { Cluster } \\
\text { ONE }\end{array}$ & $\begin{array}{c}\text { Cluster } \\
\text { TWO }\end{array}$ & $\begin{array}{c}\text { Cluster } \\
\text { THREE }\end{array}$ & $\begin{array}{c}\text { Cluster } \\
\text { FOUR }\end{array}$ & $\begin{array}{c}\text { Cluster } \\
\text { FIVE }\end{array}$ & $\begin{array}{c}\text { Cluster } \\
\text { SIX }\end{array}$ \\
\hline 1. & SDG Index & 78.3571 & $84.2000^{*}$ & 76.5250 & 74.0000 & $70.5000^{* *}$ & 78.2750 \\
2. & EU funds to GNI & 1.3066 & $0.4896^{* *}$ & 2.1302 & $2.6423^{*}$ & 1.9892 & 0.5770 \\
3. & Experience (I) & $6.9842^{*}$ & 5.8603 & $4.3910^{* *}$ & 5.0481 & 5.5014 & 4.6006 \\
4. & Engagement (I) & $8.4027^{*}$ & 6.5327 & $3.1146^{* *}$ & 7.5779 & 8.0603 & 7.1471 \\
5. & Attitudes (I) & 6.2189 & $6.4399^{*}$ & 5.3738 & 6.1398 & $3.2142 * *$ & 5.7619 \\
6. & Approval (I) & 5.8464 & 3.6456 & $2.9237^{* *}$ & 5.4596 & 6.0500 & $6.4155^{*}$ \\
7. & Expectations (I) & $6.8982^{*}$ & 6.34892 & 5.1742 & 6.3596 & $3.8540^{* *}$ & 6.0269 \\
8. & Resilience (S) & 6.2353 & $6.7098^{*}$ & 5.7368 & 4.7252 & $3.5737^{* *}$ & 5.4816 \\
9. & Economic Ties (S) & $6.5924^{*}$ & 4.7039 & 6.2600 & 6.4260 & $3.7383^{* *}$ & 4.3718 \\
10. & Funding (S) & 3.3058 & 2.8405 & 4.7084 & $5.0608^{*}$ & 3.7678 & $2.7494^{* *}$ \\
11. & Security (S) & 3.1878 & 3.7238 & 4.3000 & 3.1020 & $2.0000^{* *}$ & $10.0071^{*}$ \\
\hline
\end{tabular}

* maximum value for the selected variable; ${ }^{* *}$ minimum value for the selected variable. Source: own construction using SPSS.

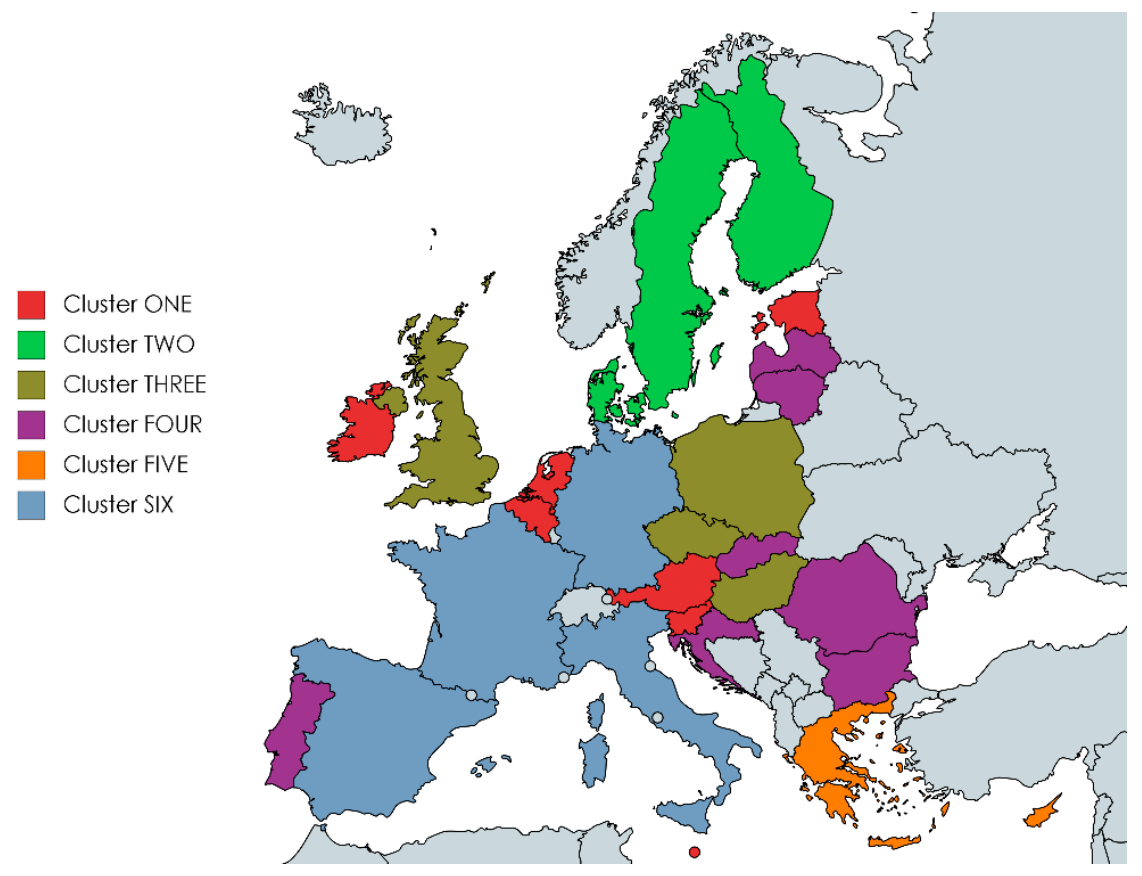

Figure 2. EU member countries clusters. Source: own construction.

As advocated by the policies, strategies and outcomes of the programs implemented across all EU member countries and our research, it highlights a new direction for the future, a new dynamic and why not, a different nucleus of sustainable competitiveness and associated growth.

We emphasize that the cohesion policy in the EU member countries mainly reflects the objectives of regionalization and implementation of the Europe of the Regions strategy and of the Lisbon Agenda related to the Europe 2020 Strategy on Sustainable Development. Practically, we highlight a set of changes that have mainly led to the transition and consolidation of democratic and institutional structures, but also to the weaker development of peripheral regions, to political centralization and regional competition.

We also mention that although the influence of the EU has been beneficial for all Member States by providing advice and good practice on sustainable development policies, it has called for respect 
for "ex-ante conditionalities", thereby limiting the area of action of Member States in the choice of policy directions.

The cohesion policy and sustainable development have truly become the main investment strategies at EU level, through the direct orientation of measures towards sustainable competitiveness, and also by supporting current polarization processes in the EU regions.

Although cohesion policy has permanently pursued the sustainability of the EU's sustainable competitiveness, it is not neglected in this context that it has moved away from its main objective, namely to promote space cohesion by supporting balanced development at regional and local level.

From another perspective, we find that EU cohesion policy from 2014 to 2020 has been redirected towards regional growth and the competitiveness issue has remained the pillar of regional convergence. This emphasizes the idea that this approach is a framework for action that can aggravate the phenomenon of disparity, the economic performance of the EU states, emphasizing the unbalanced space relations identified and manifested today. In conjunction with all of these, our research has mainly taken into account the priorities of the 2020 sustainable growth of the Member States, namely smart, sustainable and inclusive growth.

As practical experience demonstrates, the representative objectives for these three priorities have generated a wide range of actions at national and European level. In this respect, we identify a comprehensive set of initiatives to stimulate the individual, sustainable progress of each European country, namely: access to funding for research and innovation (by investing 3\% of GDP in R and D), increasing the performance of educational systems to facilitate young people's integration into the labor market (by increasing the employment rate of the population aged 20-64 to 75\%), digital market development promoting energy efficiency and developing a sustainable industry (by increasing the share of renewable energy sources in final energy consumption to $20 \%$ and increasing with $20 \%$ the energy efficiency), better adapting supply and demand for labor, ensuring social and territorial cohesion so that people experiencing poverty and social exclusion can play an active role in society (by reducing with 25\% the number of Europeans living below the national poverty lines) [61]. All these priorities and objectives are covered by the selected variables, the results of the research providing the opportunity to observe the path of each Member State in order to get an overview of the progress made.

\section{Conclusions}

The impact of implementation of cohesion policy on the sustainable development of EU countries is of great interest and presents a number of challenges. So through this research we have proposed to evaluate the impact and effects of the cohesion policy with hierarchical clustering analysis in order to identify how the selected variables affect the sustainable development models adopted by the EU countries.

These objectives were, moreover, our starting point for present research, these being structured into a set of 10 variables that generated segmentation and grouping of countries in six clusters, reflecting the level of sustainable development but also economic cohesion. "Experience", "Engagement", "Attitudes", "Approval", "Expectations", "Resilience", "Economic Ties", "Funding", "Security" and "EU funds to GNI" are the analyzed cohesion variables, the key elements of cohesion policy, well-founded instruments and sustained by local programs derived from the global sustainable development strategy.

Research has shown that cohesion policy has been used as an economic growth tool, especially in Central and Eastern European countries. This highlights the fact that traditional cohesion policy objectives supporting regions that are lagging behind are still considered important for stabilizing socio-economic processes linked to sustainable development but also by regional decline.

Moreover, since cohesion policy has been extended to all regions of Europe and the differences between the more developed, transition and least developed regions have faded, it is now extremely useful to reconsider the relevant institutional arrangements incorporated in the policies and strategies of the Europe region. At the same time, developed countries are still an essential condition for 
successful partnerships with governments of less developed countries through the implementation of cohesion policy programs, whether or not they are exclusively focused on economic development.

We can therefore conclude that cohesion policy needs to be reoriented, through the transition from traditional investment in infrastructure and social support from underdeveloped regions to innovation, alongside social and environmental strategies.

Regardless of the context, it is obvious the impact of political interventions, which have different results according to the level of development of each state. This is also visible in the grouping of the analyzed countries in our research and grouping them in the 6 clusters. Moreover, in a period of uncertainty about cohesion policy and the very meaning of cohesion policy, efforts must be made to demonstrate its relevance by clearly highlighting economic performance, sustainable development and other effects.

From this point of view, our research highlights how aspects of sustainable development influence country performance and implicitly the effectiveness of cohesion policies implemented at member country level.

We highlight a number of countries, at different levels of performance, interacting with other European cultures in a positive way, the desire for cooperation, the involvement of citizens in economic, social and political life, and they are also at high levels. In support of this idea, our research identifies countries such as Austria, Belgium, Estonia, the Netherlands, Slovenia, Ireland and Malta, countries where the expectations of the population regarding the future of the staff are positive. On the other hand, from an economic perspective, these countries have a very high level of integration with the other European countries.

From the perspective of the sustainable development achieved, we identify the Nordic countries, Denmark, Finland and Sweden, the countries with the highest performance and which also have the highest values for two of the cohesion variables analyzed, respectively for "Attitudes" "Resilience". Research highlights the fact that these countries with a very high level of prosperity are much more inclined to cooperate with the citizens of other countries within the European Union. Interestingly to be emphasized is the fact that, from the perspective of the European funds allocated, the average value for the three countries clustered in this cluster is the lowest of all the analyzed clusters.

At the other end, countries that can be characterized by a relatively low level of interaction with other European citizens, respectively with other EU Member States, are those included in Central Europe (Czech Republic, Hungary and Poland) where and the United Kingdom, as well as the lowest values for experience, involvement and endorsement. With relatively low scores on the level of sustainable development achieved but showing the highest values in the percentage of European funds in the GNI among all the analyzed countries, we highlight Bulgaria, Romania, Croatia, Lithuania, Portugal, Latvia and Slovakia. We highlight that, at the level of European Cohesion Policy, achieving the objective of reducing economic and social disparities has generated significant investment by allocating funds consistently to these less developed countries. It also signals that these countries also have a high potential for cohesion, through higher than average scores for "Engagement", "Attitudes" and "Expectation" variables.

A very important conclusion of our study is that of Cyprus and Greece. These two countries are analyzed separately, as the underlying research indicates the lowest values for 5 of the 9 analyzed cohesion variables, namely "Attitudes", "Expectations", "Resilience", "Economic Ties" and "Security". These two countries also record a relatively low sustainable development level with the lowest average value of the SDG Index as well as coefficients of cohesion variables that do not reflect a high enough support to improve this condition in the near future. With conflicting companies that directly affect prosperity, Cyprus and Greece record the lowest level of trade integration with other European countries.

At the opposite end, the most economically important countries at European level are: France, Germany, Italy and Spain. Our research reflects the highest values for "Approval" and "Security" for these countries, but on the other hand the lowest value for "Funding". With a positive perception 
of the results of the implementation of European policies, but also with a level of security perceived as the highest of all the analyzed countries, France, Germany, Italy and Spain, they also record a very high level of economic development, which justifies the low level of funding received from the European Union.

Along with the conclusions highlighted above, not least, our research is also a reflection paper on options for improving cohesion policy. We highlight issues that may be the subject of debates and corrections, namely: new regulations on existing funds, other funding instruments centered on sustainable regional projects, identifying new criteria for funding and increasing cohesion, including in EU border regions, a much more radical approach simplifying the implementation of cohesion policy and sustainable development.

Among the most important recommendations for effective policymaking to support increased cohesion and the achievement of the proposed SDP, we could mention: improvements in education and healthcare (leading to higher income and better environmental decisions), encouraging responsible consumption and production (based on circular economy approach), sustaining and promoting Smart cities initiatives, or supporting the ongoing digital revolution.

As far as the limitations of this paper are concerned, we may take into account that the research carried out is based on data currently available, which are provided by official EU institutions but also by third parties. The way of calculating the indices and variables used in the analysis is specific to these data providers, and the results obtained may differ depending on the methodology used.

However, the results obtained from this research can be considered as a step forward in identifying the most appropriate public policies to help support countries with lower performances than the European average, based on examples of good practices and country successes more efficient. Analyzing the progress of countries with notable performances (such as those included in Cluster ONE, TWO, or FOUR), along with ways in which examples of good practice have been successfully identified and replicated, can turn into a successful recipe that can be used to support Member States wishing to make more sustained progress in sustainable development.

As future research directions, we aim to closely monitor the evolution of the current situation and the progress made by the Member States in order to identify the influence of the individual vectors that influence the impact of the implementation of the cohesion policy on sustainable development. With the completion of the Multiannual Financial Framework for 2014-2020, new data will be available and the progress achieved will be better documented. Also, it would be important to investigate the causes and factors that negatively influenced the performances of some countries (especially those included in Cluster THREE and FIVE), which has generated far below expectations in terms of the results of the Cohesion Policy, but also in the field of sustainable development.

Author Contributions: Data curation, C.D., S.D. and A.G.; Formal analysis, M.L. and A.G.; Investigation, S.D. and M.L.; Methodology, R.P.; Project administration, R.P.; Resources, G.A.; Software, C.D. and G.A.; Supervision, R.P.; Validation, S.D.; Visualization, A.G.

Funding: This research received no external funding.

Conflicts of Interest: The authors declare no conflict of interest.

\section{References}

1. Hadjimichalis, C.; Hudson, R. Contemporary Crisis Across Europe and the Crisis of Regional Development Theories. Reg. Stud. 2014, 48, 208-218. [CrossRef]

2. Cichowicz, E.; Rollnik-Sadowska, E. Inclusive Growth in CEE Countries as a Determinant of Sustainable Development. Sustainability 2018, 10, 3973. [CrossRef]

3. Raszkowski, A.; Bartniczak, B. Towards sustainable regional development: Economy, society, environment, good governance based on the example of Polish regions. Transform. Bus. Econ. 2018, 17, 225-245.

4. Ezcurra, R.; Pascual, P.; Rapún, M. Regional polarization in the European Union. Eur. Plan. Stud. 2006, 14, 459-484. [CrossRef] 
5. Beyer, R.C.; Stemmer, M.A. Polarization or convergence? An analysis of regional unemployment disparities in Europe over time. Econ. Model. 2016, 55, 373-381. [CrossRef]

6. Storper, M. Separate Worlds? Explaining the current wave of regional economic polarization. J. Econ. Geogr. 2018, 18, 247-270. [CrossRef]

7. Vasconcellos Oliveira, R. Back to the Future: The Potential of Intergenerational Justice for the Achievement of the Sustainable Development Goals. Sustainability 2018, 10, 427. [CrossRef]

8. European Commission. Towards a Sustainable Europe by 2030. 2019. Available online: http://ec.europa.eu/ transparency/regdoc/rep/1/2019/EN/COM-2019-22-F1-EN-MAIN-PART-1.PDF (accessed on 10 May 2019).

9. European Commission. Stimulating Innovation through the Cohesion and Environmental Policies. 2007. Available online: http://ec.europa.eu/environment/archives/integration/pdf/ideas_paper_dgenv.pdf (accessed on 10 May 2019).

10. Institute for European Environmental Policy. Cohesion Policy and Sustainable Development. Cohesion Policy Performance, Supporting Paper 2. 2012. Available online: https://ieep.eu/publications/cohesion-policy-andsustainable-development-cohesion-policy-performance-supporting-paper-2 (accessed on 15 May 2019).

11. Sirje, P.; Üllas, E.; Koidu, T. The impact of EU Cohesion policy on environmental sector sustainability in the Baltic states. Balt. J. Econ. 2010, 10, 23-42.

12. Boström, M. A Missing Pillar? Challenges in theorizing and practicing social sustainability, Sustainability: Science. Pract. Policy 2012, 8, 3-14.

13. Mendez, C. The Lisbonization of EU Cohesion Policy: A Successful Case of Experimentalist Governance? Eur. Plan. Stud. 2011, 19, 519-537. [CrossRef]

14. Lois González, R.C.; Paül, V.; Trillo-Santamaría, J.-M. The Territorial Dimension of “Europe 2020”: Mapping European Regions under the Strategy to Emerge from the Crisis. Soc. Sci. 2014, 3, 13-27. [CrossRef]

15. Tulumello, S. Multi-level Territorial Governance and Cohesion Policy, Structural Funds and the Timing of Development in Palermo and the Italian Mezzogiorno. Eur. J. Spat. Dev. 2016, 62, 1-23.

16. Adshead, M. EU cohesion policy and multi-level governance outcomes in Ireland: How sustainable is Europeanization? Eur. Urban Reg. Stud. 2014, 21, 416-431. [CrossRef]

17. McCann, P.; Ortega-Argilés, R. Smart Specialization, Regional Growth and Applications to European Union Cohesion Policy. Reg. Stud. 2015, 49, 1291-1302. [CrossRef]

18. Bruszt, L. Multi-level Governance-The Eastern Versions: Emerging Patterns of Regional Developmental Governance in the New Member States. Reg. Fed. Stud. 2008, 18, 607-627. [CrossRef]

19. Hudson, R. European Integration and New Forms of Uneven Development: But Not the End of Territorially Distinctive Capitalisms in Europe. Eur. Urban Reg. Stud. 2003, 10, 49-67. [CrossRef]

20. Gross, M.; Debus, M. Does EU regional policy increase parties' support for European integration? West Eur. Politics 2018, 41, 594-614. [CrossRef]

21. Avdikos, V.; Chardas, A. European Union Cohesion Policy Post 2014: More (Place-Based and Conditional) Growth-Less Redistribution and Cohesion. Territ. Politics Gov. 2016, 4, 97-117. [CrossRef]

22. European Committee of Regions. The Committee of the Regions' White Paper on Multilevel Governance. 2017. Available online: https://publications.europa.eu/en/publication-detail/-/publication/3cba79fd-2fcd4fc4-94b9-677bbc53916b/language-en (accessed on 20 May 2019).

23. Florio, M.; Morretta, V.; Willak, W. Cost-Benefit Analysis and European Union Cohesion Policy: Economic Versus Financial Returns in Investment Project Appraisal. J. Benefit Cost Anal. 2018, 9, 147-180. [CrossRef]

24. Dettmer, B.; Sauer, T. Implementation of European Cohesion Policy at the sub-national level: Evidence from beneficiary data in Eastern Germany. Pap. Reg. Sci. 2019, 98, 167-189. [CrossRef]

25. Mendez, C. Clouds, Clocks and Policy Dynamics: A Path-(Inter) Dependent Analysis of EU Cohesion Policy. Policy Politics 2012, 40, 153-170. [CrossRef]

26. Barca, F. An Agenda for a Reformed Cohesion Policy A Place-Based Approach to Meeting European Union Challenges and Expectations; EERI Research Paper Series EERI_RP_2008_06; Economics and Econometrics Research Institute (EERI): Brussels, Belgium, 2008.

27. Drometer, M.; Nam, C.W. R\&D and Innovation Support in the Evolving EU Cohesion Policy, CESifo Forum, ISSN 2190-717X, ifo Institut -Leibniz-Institut für Wirtschaftsforschung an der Universität München. München 2018, 19, 37-42. 
28. Telle, S.; Špaček, M.; Crăciun, D. Divergent Paths to Cohesion: The (Unintended) Consequences of a Place-Based Cohesion Policy. In Regional and Local Development in Times of Polarisation; New Geographies of Europe; Lang, T., Görmar, F., Eds.; Palgrave Macmillan: Singapore, 2019.

29. Loewen, B.; Schulz, S. Questioning the Convergence of Cohesion and Innovation Policies in Central and Eastern Europe. In Regional and Local Development in Times of Polarisation; New Geographies of Europe; Lang, T., Görmar, F., Eds.; Palgrave Macmillan: Singapore, 2019; pp. 121-148.

30. European Commission. My Region, My Europe, Our Future: The Seventh Report on Economic, Social and Territorial Cohesion. 2017. Available online: https:/eur-lex.europa.eu/legal-content/FR/TXT/?qid= 1508317360588\&uri=CELEX:52017SC0330 (accessed on 25 May 2019).

31. Dawid, H.; Harting, P.; Neugart, M. Cohesion policy and inequality dynamics: Insights from a heterogeneous agents macroeconomic model. J. Econ. Behav. Organ. 2018, 150, 220-255. [CrossRef]

32. Amar, A. Building Socio-Ecological Coviability: An Efficient Way to Combat Poverty, Reduce Inequality and Address Insecurity Risks. In Human and Environmental Security in the Era of Global Risks; Behnassi, M., Gupta, H., Pollmann, O., Eds.; Springer: Berlin/Heidelberg, Germany, 2019.

33. KPMG. Expertise and Innovation to Drive Success: Annual Review 2016. 2017. Available online: https: //home.kpmg/content/dam/kpmg/mt/pdf/2017/04/mt-annual-report-2016.pdf (accessed on 27 May 2019).

34. Nosek, S. Territorial cohesion storylines in 2014-2020 Cohesion Policy. Eur. Plan. Stud. 2017, 25, $2157-2174$. [CrossRef]

35. Hansen, T.; Winther, L. Innovation, regional development and relations between high-and low-tech industries. Eur. Urban Reg. Stud. 2011, 18, 321-339. [CrossRef]

36. Florea, N.M.; Meghisan, G.M.; Nistor, C. Multiple Linear Regression Equation for Economic Dimension of Standard of Living. Financ. Chall. Future 2016, 1, 103-108.

37. Görmar, F.; Lang, T.; Nagy, E.; Raagmaa, G. Re-thinking Regional and Local Policies in Times of Polarisation: An Introduction. In Regional and Local Development in Times of Polarisation; New Geographies of Europe; Lang, T., Görmar, F., Eds.; Palgrave Macmillan: Singapore, 2019.

38. Nanu, R.; Buziernescu, R.; Spulbar, C.M. The experiences of the new member states in the Structural Funds field. Lessons for Romania. Ann. Univ. Craiova Econ. Sci. Ser. 2008, 5, 2315-2324.

39. Yordanova, D.; Kosuliev, A. Research on the Relationship Between EU Cohesion Policy and Development of Bulgarians Regions. Reg. Econ. Sustain. Dev. 2018, 1, 86-98.

40. Adger, W. Social Capital, Collective Action, and Adaptation to Climate Change. Econ. Geogr. 2003, 79, 387-404. [CrossRef]

41. Meadowcroft, J. Participation and sustainable development: Modes of citizen, community and organisational involvement. In Governance for Sustainable Development: The Challenge of Adapting form to Function; Edward Elgar Publishing: Cheltenhan, UK, 2004; pp. 162-190.

42. Firoiu, D.; Ionescu, G.H.; Băndoi, A.; Florea, N.M.; Jianu, E. Achieving Sustainable Development Goals (SDG): Implementation of the 2030 Agenda in Romania. Sustainability 2019, 11, 2156. [CrossRef]

43. Bodin, Ö.; Crona, B.; Ernstson, H. Social networks in natural resource management: What is there to learn from a structural perspective? Ecol. Soc. 2006, 11, 1-8. [CrossRef]

44. ESPON. Territories Finding a New Momentum: Evidence for Policy Development, Growth and Investment. 2014. Available online: https://www.espon.eu/sites/default/files/attachments/ESPON_SYNTHESIS_REPORT_ 3_0.pdf (accessed on 20 May 2019).

45. European Commission. An introduction to EU Cohesion Policy 2014-2020. 2014. Available online: https://ec. europa.eu/regional_policy/sources/docgener/informat/basic/basic_2014_en.pdf (accessed on 30 May 2019).

46. Bachtler, J.; Begg, I. Beyond Brexit: Reshaping policies for regional development in Europe. Pap. Reg. Sci. 2018, 97, 151-170. [CrossRef]

47. European Council on Foreign Relations. EU Cohesion Monitor. 2019. Available online: www.ecfr.eu/ eucohesionmonitor (accessed on 11 May 2019).

48. European Commission. Europe Moving Towards a Sustainable Future. 2018. Available online: https://ec.europa.eu/info/sites/info/files/sdg_multistakeholder_platform_input_to_reflection_paper_ sustainable_europe2030.pdf (accessed on 30 May 2019). 
49. European Commission. Assessing the 2005 European Consensus on Development and Accompanying the Initiative "Proposal for a New European Consensus on Development". 2016. Available online: https: //ec.europa.eu/europeaid/sites/devco/files/swd-assessing-2005-consensus-387-20161122_en.pdf (accessed on 29 May 2019).

50. European Commission. Sustainable Development: EU Sets out Its Priorities. 2016. Available online: http://europa.eu/rapid/press-release_IP-16-3883_en.htm (accessed on 29 May 2019).

51. Kalman, J.; Tiits, M.; Richter, S.; Mürk, I.; Kalvet, T. Coordinated Policies and Cohesion Policies: Their Relationship and Impact on the Member States; Paper 7.04; GRINCOH: London, UK, 2015.

52. European Commission. ESIF 2014-2020 EU Payments. 2019. Available online: https://cohesiondata.ec. europa.eu/2014-2020/ESIF-2014-2020-EU-payments-daily-update-/gayr-92qh (accessed on 5 June 2019).

53. Sachs, J.; Schmidt-Traub, G.; Kroll, C.; Lafortune, G.; Fuller, G. SDG Index and Dashboards Report; Bertelsmann Stiftung and Sustainable Development Solutions Network: New York, NY, USA, 2018.

54. Everitt, B.S.; Landau, S.; Leese, M. Cluster Analysis, 4th ed.; Wiley Publishing: Hoboken, NJ, USA, 2009.

55. Ward, J.H. Hierarchical Grouping to Optimize an Objective Function. J. Am. Stat. Assoc. 1963, 58, $236-244$. [CrossRef]

56. Popa, M. Statistică Pentru Psihologie. Teorie și Aplicații SPSS Ediţia a II-a Revăzută şi Adăugită; Polirom: București, Romania, 2008.

57. Zaharia, M.; Oprea, C. Elemente de analiza datelor și modelare utilizând Excel; Editura Universitară: București, Romania, 2011.

58. Rotaru, T.; Badescu, G.; Culic, I.; Mezei, E.; Mureșan, C. Metode Statistice Aplicate în Științele Sociale; Polirom: Iași, Romania, 2006.

59. Jung, Y.; Park, H.; Du, D.-Z.; Drake, B.L. A Decision Criterion for the Optimal Number of Clusters in Hierarchical Clustering. J. Glob. Optim. 2003, 25, 91-111. [CrossRef]

60. Salvador, S.; Chan, P. Determining the number of clusters/segments in hierarchical clustering/segmentation algorithms. In Proceedings of the 16th IEEE International Conference on Tools with Artificial Intelligence, Boca Raton, FL, USA, 15-17 November 2004; pp. 576-584.

61. European Commission. EUROPE 2020 a Strategy for Smart, Sustainable and Inclusive Growth. 2010. Available online: http://ec.europa.eu/eu2020/pdf/COMPLET\%20EN\%20BARROSO\%20\%20\%20007\%20\%20Europe\%202020\%20-\%20EN\%20version.pdf (accessed on 9 May 2019).

(C) 2019 by the authors. Licensee MDPI, Basel, Switzerland. This article is an open access article distributed under the terms and conditions of the Creative Commons Attribution (CC BY) license (http://creativecommons.org/licenses/by/4.0/). 